\title{
İBNI SINA'DA KIMYA
}

\author{
ESIN KAHYA
}

Sevgili Hocam Prof. Dr. Sevim Tekeli'ye

Armağan...

Kimya çalışmalarının kökleri çok eskilere gider. Tarih öncesi devirlerde başlatılabilecek olan kimya çalışmaları ilk metal işleri ve çanak çömlek yapımı olarak ortaya çıkar. Bu el sanatları herhangi bir temele ait olmaksızın gelişmiş ve malzemesinde hemen hiç değişmeye uğramadan Neolitik devirlerden günümüze kadar gelmiştir.

İnsanlar hayatlarının ilk devrelerinde metalleri bilmiyorlardı. Muhtemelen ilk tanınan metal altındı; parlaklığı ve rengiyle nehir kumlarının arasında dikkati çekmiş olmalıdır. Bakırın kullanılışı ise M.Ö. 3500'lere kadar götürülebilir. İlk metal ișlemeciliği de M.Ö. 3400'lerde Mezopotamya ve Mısır'da görülmüştür. Demirin kullanılması ve işlenmesi daha geç tarihlere, yaklaşık M.Ö. 1500'lere rastlar. Onun gümüş ve bakırdan sonra kullanılmaya başlandığı kabul edilmektedir.

Cam ve cam yapımı ile ilgili örnekler renkli cam yapımı olarak M.Ö. 3400 'lerde görülür. M.Ö. 1150 ve 1370 'lerde Mısır'dan Yunanistan ve İtalya' ya hatta İngiltere'ye kadar cam eşya ihraç edildiği bilinmektedir ${ }^{1}$.

Bugün kimyanın önemli bir kolu olan boyalar ise ilkin bitki daha sonrada hayvanlardan elde edilmeye çalışılmıştır. Örneğin bir deniz yumuşakçasından mavi boya elde edilmeye çalışılmışur.

Kimyada element ve bileşikler fikri bütün bu teknik çalışmaların başlamasından çok daha sonra ortaya çıktı. Element fikri ilk defa Yunan filozoflarından Thales (646-546), Anaximenes (560-500 B.C.) ve diğer tabiat filozofları tarafindan ortaya atıldı ve işlendi. Onlar bütün evreleri bir ya da, daha sonra bazılarında görüldüğü üzere, dört element üzerine dayandırmaya ve bu temele dayalı olarak doğadaki her şeyi açıklamaya çalışular.

1 J.R. Partington, A Short History of Chemistry, New York ,1957, s.1-11. 
M.Ö. 460-370 tarihleri arasında yaşayan Democritos evrenin yapısının atomlardan teşekkül ettiğini kabul etmiş ve bu atomların katı ve homojen olduğunu ifade etmiștir.

Büyük Yunan filozoflarından Platon ise varlığın temelinde dört elementin bulunduğunu kabul etmiş, ancak toprak, hava, su ve ateşin yanı sıra fazla gelişmeden maddi ve göksel âlemi birleştirmek üzere, bir beșinci unsur olarak eterden söz etmiştir. Aristo ise dört elementi yersel olarak kabul edip eteri mükemmel ve göklerin maddesi olarak düşünmüştür. Aristo, dört unsur için dört nitelik düşünmüştür; kuru ve yaş, sıcak ve soğuk. Unsurların her biri kendi karakterine sahiptir. Örneğin toprak kuru ve soğukluk niteliklerine sahiptir.

Simya, ilk kimyaya nispetle çok daha yakın tarihlerde ortaya çıkmıştır. Onun başlangıcı, Doğu uygarlıklarında IV. yüzyıl, Yunan'da İskenderiye Okulu ile, yani M.Ö. III. yüzyıla kadar götürülebilir. İskenderiye'de Yunan bilim adamları arasında doğmuş ve Doğu Akdeniz ve özellikle Suriye'de yayılmıştır. İslamiyet'in ortaya çıkışından sonra İslam Dünyasına yayılmıștır. Daha sonra İspanya'da ilgi görmüştür. XII. yüzyılda İtalya'da aynı paralelde görüşlerin yayıldığını görüyoruz².

1) Simyanın kökeninde sır bulunduğu için ilgi çekmiştir. Mısır'ın yanı sıra, Çin'de, Hint'te, Mezopotamya'da da aynı tip çalıșmalara rastlanır. Çin'deki simya çalışmaları ile Batıdakiler paralelizm gösterirlerse de, bu ikisi arasında bir münasebet olduğuna dair bir delil bulmak mümkün olmamışur.

2) M.Ö. 1000'lerde Hindistan'da ölümsüzlük iksiri şeklinde etkin bir ilaç fikri mevcuttu ve aynı devirlerden kalmış Atarvavedalarda simya ile ilgili fikirlere rastlanmaktadır. Her ne kadar kesin değilse de, bu fikirlerin Çin'deki simya çalışmalarını etkilemiş olma ihtimali vardır.

Çin'deki ilk simya çalışmaları M.Ö. IV. yüzyıl olarak tarihlendirilmektedir. M.Ö. 60'da İmparatorun 'Reçetelerin Efendisi Lia Hsiang' adlı tanınmış alimi, hayatını uzatması ve altın yapması için tuttuğu bilinmektedir. Altın yapmak için doğal kırmızı cıva sülfürü (cinnabar veya zencefre) kullanıyorlardı. Bunun kırmızı rengi muhtemelen kanın kırmızı rengiyle bağıntılıydı. O, el-iksire ya da gizli bir ilaca dönüştürülüyordu. Batı'da da fi-

${ }^{2}$ Aaron J. Ihne, The Development of Modern Chemistry, New York 1966, s.6-10. 
lozof taşı denen maddenin ilkin beyaz, sonra da kırmızıya dönüştüğü bilinir. Zencefre altun yapmak ve ömrü uzatmak için kullanılmıştur ${ }^{3}$.

Yunanca konuşan yerlerde yetişmiş ilk simyagerler hakkında çok kesin bilgi edinemiyoruz. Simya döneminin, yaklaşık olarak M.Ö. en erken 300'e kadar geri gittiği ve M.S. 200'lerden itibaren de İskenderiye'de yavaş yavaş gerilemeye başladığı söylenir.

Genel kanaate göre, simya ile ilgili ilk eserler M.S. 100'lere aittir. Fakat bazı yazarlar bu konudaki ilk yazılı belgeleri Düzmece Democritos'a (M.S. 250) atfederler ve genellikle ilk simyagerler olarak şu isimleri sayarlar; Düzmece Democritos (Yunan filozofu), Isis (Mısır tanrıçası), Iamblicus (M.S. 330 Yunan filozofu), Musa (Yahudi peygamber), Ostanes (efsanevi İranlı bilgin), Kleopatra (Mısır kraliçesi), Hermes (efsanevi bir tanrı), Agathodaemon (yılan tanrı), Pibechios (bir tanrı: Apolla Bechis).

Panapolis'li Zosimos (yaklaşık M.S.III. yüzyıl) bazı parçaları bugüne kadar kalmış bir ansiklopedi yazmıştır. Bu eser simya, sihir ve mistik yazıları içerir ${ }^{4}$.

Yunanlı simyagerler M.S. 200'lerde yazmış oldukları eserlerin başına Hermes, Isis, Agathedaemon gibi adlar koymuşlardır. Çin'deki eski kitapların yenilerden daha çok hürmet göreceğini ve adı duyulmamış çağdaş bir yazardan, tanınmış eski bir adın daha çok ilgi çekeceğini düşünmüşlerdir. Bundan dolayı genellikle simya ile ilgili yazarların yazıları konusunda şüphe uyanmıştır.

Her ne kadar simya ile ilgili ilk yazılı metinler Yunanca ise de, yazarlarının pek çoğu Yahudi ya da Mısırlı, Hıristiyan değillerdi, ancak Mısır mitolojisinin deyimlerini kullanıyorlardı; Yunan felsefesine aşina idiler; genellikle laboratuarda çalışan kişilerdi. Simyagerlerin bazıları kadındı; örneğin Yahudi Mary (Miriam) (Popnutia'lı), Zosimus'un kız kardeşi Theosobiea gibi.

Bu simyagerler kıymetli metaller ve taşlar yapmaya çalışmışlardır. Şüphesiz bunların içinde en önemli yeri altın teşkil etmiştir. Eskilere göre "altun" başka temel metallerin çeşitli oranda saf altunla birleşmesinden meydana gelmiyordu. Altın parlak, sarı, kararmaz, ağır, ateşe dayanıklı bir mad-

${ }^{3}$ F.Sherwood Taylor, The Alchemists, Londra 1953, s. 68-75.

4 George Sarton, Introduction to the History of Science, Baltimore (USA) 1927 c.I., s. 238-339. 
deydi; 1sıtılınca değişikliğe uğramıyordu. Altının özgül ağırlığı eskilerin bildiği hiçbir metale benzemiyordu. Ancak onun gibi sarı, sert ve yoğun bir madde elde edilebiliyordu. Gümüşe benzer madde yapmak daha kolaydı, çünkü birçok beyaz renkli karışım ve alaşım elde etmek mümkündü. Örneğin bakırı arsenikle karıștırıp, beyazlatarak gümüss, sarı arsenikle (arsenik sülfür) muamele ederek altun elde etmeye çalışmışlardı.

Genel olarak eski simyagerler dört temel metot kullanmışlardır;

1) Bakır ve çinko gibi temel metallerin pirinç gibi alaşımlarını yapma

2) Düşük ayarda altın hazırlanması

3) Metal ya da alaşımların yüzeysel renklendirilmesi

4) Distile edilmiş sıvıların kullanılmasıyla ya da metalleri buharlaşturmaya tabi tutarak çok karmaşık bir seri işlem.

$\mathrm{Bu}$ metotlara destek olarak verilmiş olan reçeteleri içeren Leyden Papirüsü 1828'de Mısır'da bir türbede bulunmuştu. Onun bir kısmı Stockholm' e yollandığı için Stockholm Papirüsü adını almıştı. Papirüs Yunancadır; yaklaşık M.S. 300'lerde kaleme alınmıştur; içinde 300 tarif vardır, ancak bazı tariflerin daha eski tarihli, Mısır kaynaklarından kopya edilmiş olması olasılığı yüksektir.

Leyden Papirüsü altın ve gümüş alaşımlarıyla ilgilidir. Bunların aslından daha iyi olduğu vurgulanır. Stockholm Papirüsü boyalar, kıymetli taşlar ve onların taklitleriyle ilgilidir ${ }^{5}$.

Yunan bilimi zirvedeyken Orta Doğu'da başka kültürler mevcuttu. Hindistan'da, İran'da ve Suriye'de astronomi ve matematik çalışmalan yapıldığını biliyoruz. Aynı zamanda tabiat felsefesiyle ilgili fikirlerin de geliştiğini belirleyebiliyoruz. Bu arada bazı önemli kültür merkezlerinin teşekkül etmeye başladığını ve bu merkezlerde çeşitli kültürlerin karşılaştığını da görüyoruz. Örneğin Güneydoğu Anadolu Süryani, Yunan ve İran kültürünün karşılaşığı yer olmuştur.

M.S. 431 yılında İstanbul'dan çıkan Nesturi bilim adamları Suriye'nin kuzeyinde, Edesa'da (Urfa) bir okul kurdular. Müteakip yıllar içinde ilkin 1889

${ }^{5}$ M. Bertelot, Introduction à l'Étude de la Chimie des Anciens et du Moyen Age, Paris, 
Nisibis (Nusaybin) ve M.S. 500'lerde de Jundişapur'a yerleştiler. Onlar Yunanca biliyorlardı ve birçok Yunanca eseri Süryaniceye çevirdiler.

Müteakip yüzyılda monofizitler İstanbul'a gelip oradan dönüşte, Suriye ve İran'a göç ettiler. Bunlardan bir kısmı simyayla ilgili bazı Yunanca eserleri Arapçaya çevirmişlerdir.

622 ve 750 yılları arasında yeni bir din, İslamiyet ortaya çıkarak, Anadolu, Suriye, Mısır ve Afrika'yı içine alan bir sahada süratle yayıldı. 750 yıllarından itibaren idareyi ellerinde tutan Abbasi Halifeleri bilimsel çalışmalarla ilgilendiler ve halifelerin de desteği ile felsefe, matematik ve diğer bilimsel eserler, Yunanca'dan ve Süryanice'den Arapça'ya çevrildi. Bu çeviriler sayesinde İslam dünyası İskenderiyeli bütün simyagerleri öğrendiler; Hermes, Isis, Agathodaimon gibi efsanevi figürler de onlar arasındadır. Simya için en önemli kaynak Hermes'e atfedilmiş eserler olmuştur. Hermes bir Yunan tanrısı olup simyanın kurucusu olarak kabul edilir. İslam kaynaklarında Hermes 3 terim haline gelmiștir.

Hermes Trismegistos (Arapça el-Muthallah bi'l-Hikme) 3 Hermes, 3 Peygamber olarak düşünülmüştür. İlk Hermes İdris peygamber olarak kabul edilmiş; ikincisi el-Babih, üçüncüsü ise İdris peygamber gibi Mısır'da yaşamıştır. Hermes sadece simyanın değil, aynı zamanda astronomi, astroloji ve diğer birçok sanatla felsefenin kurucusu olarak düşünülmüş ve ilk Hermes Ebu'l Hükema (filozofların babası) diye adlandırılmıștı. Hermes'in yazıları İslam dünyasını etkilemiştir.

İskenderiye'deki simya çalışmalanı konusunda İslam dünyasında görülen çalışmalar erken tarihte başlamışt. Illk Müslüman simyager olarak Umeyye prensi Halid b.Yezid'in adı zikredilir. O, simyaya ilgi duymuştu. Onun günümüze kadar gelen eserleri vardı. Bazıları ise daha sonra bu konuda çalışanlar tarafından zikredilmiștir.

İslam dünyasında VIII. yüzyılda İmam Cafer el-Sadık da simya ile ilgilenenlerdendi. $\mathrm{O}$, altuncı imamdı; İslam dünyasının meşhur simyagerlerinden Cabir b. Hayyan'ın hocası olmuştur ${ }^{6}$.

Cabir İbn Hayan, Bermeki ailesindendir. Özellikle altın ve gümüş yapımıyla ilgilenmişti. O çok tanınmış ve önemli bir kişiydi. Razi onun için 199.

${ }^{6}$ Seyyed Hussein Nasr, Islamic Science, An Illustated Study, Kent (Ingiltere) 1976. s.197- 
“öğretmenimiz Ebu Musa Cabir İbn Hayyan” demektedir. 'O, el-iksir yapıyordu"7 şeklinde Ibn Nedim'in tanımladığı Cabir Ibn Hayyan ya da Batının verdiği isimle Geber, birçok simya eseri kaleme almıştur. Bazılarına göre, onların hepsi Cabir Ibn Hayyan'a ait olmaypp, gizli bir grubun üyeleri tarafindan yazılmıştr.

Cabir Ibn Hayyan,Yunanlı simyagerler hakkında bilgi sahibi idi. Biz söz konusu yazarların birçoğunun çalışmalarını bilmediğimizden Cabir'in çalışmalarının ne kadar orijinal olduğunu söylememize imkan yoktur. Cabir de, daha önceki simyagerler gibi, altın yapımına öncelik tanımış ve altın yapımı için bir teori geliştirmişti. Ona göre cevherler şöyle ayrılabilir:

a) Uçucu olan maddeler: kafuru, amonyak tuzu, cıva, arsenik ve kükürt gibi.

b) Metalik maddeler: yani metaller;

c) Cisimler: yani uçucu olmayan maddelerin ve metallerin dışında kalanlar.

Yaş ve kuru buharlar cıva ve kükürt buharlarından meydana gelir. Bunlar kayalarla birleşip metalleri meydana getirir. Metallerin birbirinden farklı oluşları içlerinde ihtiva ettikleri kükürt oranından kaynaklanmaktadır.

Bu devirde özellikle sık sık uçabilir, yanabilir tabirleri kullanılmışur. Kükürdün birçok çeşitleri kullanılmıştır. Onları renkleriyle ayırt etmişlerdir; beyaz, siyah, yeşil gibi. Cabir b. Hayan kükürdü uçabilir bir madde olarak kabul etmektedir. Metaller her ne kadar uçabilir madde olarak kabul edilmişlerse de, aynı zamanda dört elementi de yani toprak, hava, su, ateşi de içerir. Bu elementlerin kuruluğu, yaşlığı, sıcaklığı ve soğukluğu da farklidir.

Bir maddenin gümüş ya da altuna dönüşmesi (transmutasyon) yukarıda bahsedilen özelliklerinde değişiklik meydana gelmesi demektir. Bunun için nemlilik, sıcaklık, soğukluk ve kuruluk özelliklerinin değişmesi gerekir.

O dönem tıbbında aynı kaliteler mevcuttu. Bu kalitelerden birinin fazlalığı insan sağlığının bozulmasına sebep oluyordu. Cabir, el-iksir denen ve temelinde metallerin bulunduğu tubbi terkiplerle insandaki bozulan bu dengeyi sağlamaya çalışıyordu. El-iksirin hazırlanmasında her şeyden önce 4 un-

7 Bayard Dodge (ed) The Fihrist of al- Nadım, c. II, New York 1970, s 853-860. 
surun oranın iyi belirlemek gerekiyordu. Her ne kadar burada modern kimyayı haturlatan bir nokta varsa da metallerin 4 unsura ayrışturılamayacağını da göz önünde bulundurmak gerekir.

Cabir, organik cisimleri distile etmek suretiyle ayrışturabiliyordu ve bu muhtemelen İskenderiyelilerden gelen bir fikirdi; tupkı Zosimus'un yumurtayı damıtmaya çalışması gibi. Bu yolla hayvan pisliğinden amonyak tuzu elde edilmişti.

Herhangi bir organik cisim damıtunca:

1) siv (su elementi)

2) yağ (katı veya sıvı yağ kısmı). Bu kısım muhtemelen yanabilir kısımlardandır.

3) yanabilir renkli madde veya alev (sıcak ve kuru vasfinı taşır.)

4) kuru bir mineral artı̆̆ ( kömür ve toprak elementleriyle aynıdır yani soğuk ve kuru olur) elde ediliyordu.

Cabir'e göre, bütün mevcut maddeler iki özelliğe sahiptir ancak 'saf element' bir tek özelliğe sahip olma eğilimi gösterir. Öyle bir elemente başka bir özellik ilave etmek suretiyle istenilen metal elde edilebilir. Örneğin suyu damıtalım ve işlemi tekrar tekrar yapalım. Sonuçta tupkı tuza benzer beyaz ve parlak bir madde elde ederiz. Bazılarına göre o damıtma işlemini 700 defa tekrarlamıştır. Bugün biz Cabir'in bu iddiasının doğru olup olmadığını gösteremiyoruz. Çünkü suyun değişmesi diye bir olayla karşılaşmıyoruz.

Burada Cabir islak bir maddeden kuru bir madde meydana getirmeyi başarmıştır. Onun elde ettiği madde, toprak özelliklerini taşır yani kurudur; parlaktır; filozof taşına benzer. Cabir b. Hayyan'ın gerek el-iksir çalışmalarında, gerekse altın ve gümüş elde etmek için yapmış olduğu çalışmalarda önemle üzerinde durduğu nokta miktar ve oran fikridir. Çünkü ancak belirli oran ve belirli miktarlar sayesinde olumlu sonuç elde edilebilecektir ${ }^{8}$.

Cabir'den sonra İslam dünyasında bu konularla ilgilenen en önemli kişi Razi'dir. Razi (864-923) Reyli'dir. O, felsefe, simya, matematik, tup, ahlak ve

${ }^{8}$ F. Sherwood Taylor, s. 76-85. 
müzik gibi konularla ilgilenmişti. Onun en önemli yazıları simya ve tupla ilgili olanlaridır.

Razi kendisini Cabir'in öğrencisi olarak görür ve onun simya ile ilgili yazıları Cabir'inkilere büyük benzerlik gösterir. O, şeylerin (nesnelerin) içyapılarını, özelliklerini açıklama metodunu izlerken, olayların sembolik ya da iç anlamıyla da ilgilenir. Razi kehanete dayanan ya da ruhlara bağlı açıklamaların olasılığını reddetmiştir. O, simyanın sembolik yayılımını kabul etmez. Halbuki Cabir b. Hayyan bu konuya geniş yer vermiştir'. Razi'nin simya ile ilgili olarak yazdığı eserler aslında ilk kimya eserleriydi. O maddeyi dikkatle tasnif etmiştir. Onun Sırların Sırrı ya da Latince adıyla Liber Secretorum Bubacaris adlı eseri en meşhur simya eserlerinden biridir. O simya dilini kullanmıştır. Razi damıtma, kalsinasyon (ısıtarak değiştirme), kristalleşme v.s. ile ilgili çalışmalar yapmıştur.

$\mathrm{O}$, maddenin kimyasal ve tubbi özelliklerini vermekle kalmamış, alkol ve bazı asitler de dahil olmak üzere, bu sahada birçok keşifler yapmıştur. Bu arada deneylerini yaparken kullanmış olduğu aletler, kaplar v.s.nin pek çoğu bugün de hala kullanılmaktadır.

Razi'nin bu eserinde ele alınan konulardan biri demir gibi çok sert metallerin nasıl eritileceği ile ilgilidir. Bunun için metal, kendi ağırlı̆ının 1/4 ü kadar ağırlıkta toz arsenik sülfürle karıştırılıp bir kaba konur ve kabın ağzı çamurla kapatılarak sıcak bir firında ısıtılır. Sonra üzerine 1/6 ağırlığında sodyum karbonat ve zeytinyağı ilave edilerek tekrar karıștırılır; alta inen kısım tekrar eritilir; işlem tekrarlanabilir. Razi bakır ve altın gibi metallerin nasıl eritilebileceği konusunda da bilgi vermiştir.

Aynı zamanda o süblimleşme konusunda da bilgi vermiştir. Burada işleme tabi tutulan madde suyunu ya da nemini kaybeder. Bu işlem ateş üzerinde o maddenin tekrar tekrar ssitulmasiyla yapilır.

O aynı zamanda çeşitli tuzlar üzerinde incelemeler yapmıştur. Örneğin amonyak tuzu, alçı ve sodanın nasıl elde edileceği; ne gibi kimyasal işlemlerde kullanılabileceği konusunda bilgi verir.

Razi aynı zamanda saç ya da hayvan pisliği gibi bazı canlılardan elde edilen maddeler üzerinde de araşurma yapmıştur. $\mathrm{O}$, taze at pisliğini, aynı mik-

9 Jabir Ibn Hayan, Kitab as-Sabain (70 Kitap), Muhtar Rasail Cabir b. Hayan (ed. P. Kraus), Kahire 1354 (H.), s 511-512. 
tarda güvercin tersiyle karıştırmak suretiyle elde ettiği karışımı nemli bir örtüyle örtüp, her gün üstüne sıcak su döküp nemlendirmiştir. $O$, bu muameleyi tekrarlamak suretiyle, hayvan artıklarının muhtelif elementlere ayrıldığını söyler. Muhtemelen o, burada amonyak elde etmiştir.

$O$, zeytinyağını distile etmiş ve ondan gliserin elde etmiştir.

Yukarıda verilen bilgilerden de anlaşılacağı üzere, Razi çeşitli maddelerin birbirine dönüşebileceği görüşünden hareket ederek çeşitli denemeler yapmıştur. Bu maddelerin organik ya da inorganik oluşu herhangi bir fark yaratmamaktadır. Razi potansiyel olarak cisimlerin faal olduğunu, "ruhu" olduğunu kabul etmiştir. Ona göre, değişme herhangi bir maddenin terkibini teşkil eden şeylerin nispetlerini değiştirmek suretiyle mümkün olabilir. Razi bu süreci beş safhalı olarak düşünür:

1) kullanılan maddenin saflaşturılması;

2) onların eritilmesi;

3) çözülme yoluyla parçalara ayrılması;

4) farklı maddelerin çözeltilerinin birleştirilmesi

$$
\text { ve nihayet, }
$$

5) ürünün (elde edilen yeni maddenin) çökeltilmesi.

Razi bu konuda temelde Cabir b. Hayyan'la aynı prensiplere dayanmaktadır, ancak Cabir'in, kimya ile ilgilenen bir simyager olmasına karşın, Razi kimyasal süreçleri açıklamak için, simya dilini kullanan ve maddenin değişiminde simya inancını koruyan bir kimyagerdir ${ }^{10}$.

İslam dünyasında kimya ile ilgilenen bilim adamlarından biri de İbn Sina'dır. (980-1037) Ebu Ali el-Hüseyin b. Abdullah İbn Sina 980 yılında Harmisna kasabasında doğmuştur. Devrinin meşhur alimleri Natili ve İsmail Zahid'den ders almıştır. Matemetik, mantık, felsefe öğrenmiştir, ancak, onun en ziyade meşhur olduğu saha tıptur. O, bu konudaki maharetini Buhara Prensini tedavi ederek kanıtlanmıştur. İbn Sina çeşitli ülkelere gitmiş, hareketli bir hayat yaşamıştur.

${ }^{10}$ Seyyid Hossein Nasr, Science and Civilisation in Islam, Cambridge (U.S.A) 1968., s.268278; F.Sherwood Taylor, The Alchemists, London 1953, s. 86-87. 
İbn Sina hemen hemèn her konuyla ilgilenmiş ve bu konularda çeşitli eserler vermiştir. Bunlar arasında Kanun adlı eser önemli bir yer tutar"11.

İbn Sina 'nın diğer konularda yazılmış eserleri arasınsa Fusulu'l-İlahiyat, Ilme'l-Ahlak, Kitabal-Necat, Manzume fi'l-Mantik, Risale fi'l-Felsefe, Risale fi İbtal, Ahkam al-Nücum, Risale fi Tabir ar-Rüya, Şifa, Tefsir Suret al-Felek gibi eserleri sayılabilir. Bu eserlerin muhtelif nüshalarını İstanbul yazma kütüphanelerinde bulmak mümkündür.

Onun ilgilendiği konulardan biri de kimyadır. Bu konudaki düşüncelerini yurdumuzun çeşitli kütüphanelerinde yazma nüshaları bulunan Şifa, Risala fi Amr Mastur es-Sana' gibi eserlerinde buluyoruz.

Onun kimya ile ilgili fikirlerini özellikle adı yukarıda zikredilen ikinci esere dayalı olarak ele alıp inceleyelim.

İbn Sina'nın bazı eserlerinin ona ait olmadığı iddia edilmiştir. Bu iddiaya göre, bazı yazarlar onu şöhretinden yararlanmak istediklerinden, yazdıklan eserlere yazar adı olarak onun adını koymuşlardır. Böyle bir iddia söz konusu ettiğimiz bu eser için de bahis konusudur. Bazı kimya tarihçileri örneğin M. Berthelot, onun bazı eserlerinin Arapça asıllanı bulunmasa ve sadece Latince çevirileri olsa bile, bunun, bu eserlerin başkasına ait olduğunu göstermeye yetmediğini söylüyor. Halbuki İbn Sina'nın kimyasını ayrıntılı bir şekilde ele almış olan Ruska (Ruska, Die Alchemie des Avicenna, Isis, c.XXI, no 60, 1934, s 14-15) bu eserin İbn Sina'ya atfedilmiş kötü bir derleme olduğunu ileri sürmüştü.

Bu konuyu yeniden ele alan merhum Prof. Dr. Ahmet Ateş makaleyi ele alıp, onun çeşitli nüshalarını incelemiş, metnin tespitini yapmış ve incelemelerine dayanarak Ruska'nın iddialarını yeniden ele alarak değerlendirmiştir.

Ona göre, İbn Sina simyaya karşıdır ve bunu en güzel belirten sözleri ise onun İşarat ila İlm fasad Ahkam al-Nücum" adlı eserinde şu sözlerinde buluyoruz: "Birçok insan kolayı sever, kolayı sevenler bakırdan gümüş ve altın yapmak isterler. Bu gibi konularla uğraşan Cabir ve Razi'nin yazdıkları batuldır."

11 A.Castighoni, Histore de la Medicine, Paris 1931, s. 230; Ibn Halliktan, Tercüme-i Vefayat el-Ayan, Istanbul 1280 (H.), s.192-196; Esin Kahya, Üroloji Tarihi, Ankara 1982, s.58; İbn Sina, el-Kanun fi't-Tıbb, çev. Esin Kahya, AKM, c.1, Ankara 1996; c. 2, Ankara 2000. 
Aynı şekilde, İbn Sina Şifa adlı eserinde cansız varlığı, madenler, taşlar, ateşte eriyen maddeler, kükürtler, tuzlar diye ayırmış; onların her birinin tek tek özelliklerini vermiştir. $\mathrm{O}$, kendisine kadar gelmiş olan değişim teorisi( transmutation) ile ilgili olarak, metallerin birinin diğerine dönüşemeyeceğini, dolayısıyla bakırın ya da gümüşün altuna dönüştürelemeyeceğini söyler. Ona göre, kimyagerler yaptukları kimyasal işlemlerle bir maddeyi diğerine dönüştürmemekte, ancak iyi bir taklidini yapabilmektedirler. Çünkü hiç bir cismin özellikleri yok edilemez, ortadan kaldırılamaz.

Yukarıda verilen bilgiye dayanılarak İbn Sina'nın kimya eserlerinin bulunmadığı iddia edilebilir. Ayrıca yine Rahmetli Ateş’in de ifade etmiş olduğu gibi, genellikle Müslüman yazarlar eserlerini bir hükümdara ithaf etmişlerdir. Halbuki İbn Sina'nın olduğu iddia edilen kimya makalelerinin Latince çevirilerinde böyle bir işaret dikkati çekmemektedir. Ancak İbn Sina bir hükümdar değil, ancak bir vezire ya da prense böyle bir ithaf yapmış olabilirdi. Çünkü İbn Sina'nın olduğu iddia edilen Risale li Kimya makalesinde es-Seyyid el-Alim, Ebu'l-Hasan, Sehl b. Muhammed es-Sehli fi Amr Mastur adı geçmektedir. Sehl b. Muhammed, Abu'l -Abbas b. Memun'un veziri olarak bilinir. Abu'l Hasan Sehl b. Muhammed as-Sehli'nin, kardeşinin dostu olan İbn Sina'yı çalışmalarında destekleyip, teşvik edeceği, onun kimya ile ilgili görüşlerini destekleyeceği aşikardır. Zaten İbn Sina'nın söz konusu risalesinin başında: "Ebu'l- Hasan Sehl b. Muhammed es-Sehl ile -ki Allah onu başarılı ve yüceliğini daim kılsın- sanatın (el-kimya) gizliliği konusunda aramızda fikir alş̧verişi oldu ve benden bu konuda kendisine hatura olmak üzere, bir cüz yazmamı ve benim ulaştuğım sonuçlara, düşündüğüm yorumlara göre yol göstermemi istedi," ${ }^{12}$ şeklindeki ifadesi de bu iddiayı doğrulamaktadır.

Ayrıca bu makalede, İbn Sina'nın kimyanın aleyhinde olduğuyla ilgili olarak delil göstermek üzere Şifa adlı eserinden alınıp nakledilen bazı fikirlerin benzerlerine de rastlarız. Bu makalesinde o "fazilet ve ilme itibar eden, ona güvenen kişilerin, birçoğu kimya aklının öne sürdüğü görüşleri çürütüyorlardı. Dolayısıyla, mühim olduğundan iki grubun görüşlerini (mezheplerini) bilmem gerekliydi. Kimyanın sanat olduğunu iddia edenlerin birçoğunun kitaplarına baktum; bu sanatın temeli, kaidesi olan kıyastan onların kitaplarını boş buldum. O kitaplardaki şeyler saçmaydı ve onlara ters

12 İbn Sina, Risale el-İksir (Ahmet Ateș neșri), Türkiye Mecmuası, c. 10, 1953. s.35-53. 
düşenlerin kitaplarında ise çok zayıf, bozuk ve saçma kıyaslar buldum. Bütün bu bilgilerle bu sanat (el-kimya) çürütülemezdi." demektedir.

Bütün bunlara ilave olarak eserlerde görülen bazı fikirlerinin İbn $\mathrm{Si}$ na'nın başka eserlerinde de işlendiği görülmektedir.

Ayrıca bu risalenin İbn Sina tarafından yazıldığını gösteren delillerden birisi de Uyun el-Enba fi Tabakat el-Etibba'da bulunmaktadır. Orada bu eserin İbn Sina'ya ait olarak kaydedilmiștir. Yine el-Cüzcani de bu eserin İbn Sina tarafından yazıldığını söyler ${ }^{13}$. Bu risalenin İstanbul'daki yazma kütüphanelerinde muhtelif nüshaları vardır. Bu nüshalar Topkapı Sarayı Ahmet III,1584, 34831 (53b-58b), 3447(33b-39a),1584(126b-133b), Süleymaniye kütüphanesi Hamidiye 1447 (325a-328b), 1448(384b-390a), Ayasofya 4894(137b-1399) (baskı nüshası), İstanbul Üniversitesi Yazma Kütüphanesi 4724(A), 395A (müze kısmı) (64b-72a), 1458(A), (78a-83a), 6117(A), 4724(A), 4755(A). Ayrıca Mustafa Behçet Efendi'nin Farsça'ya çevirisi olan nüshaları Topkapı Sarayı Ahmet III 3063, İstanbul Üniversitesi Yazma Kütüphanesi 1458(A) (159a-161b) de bulunmaktadır.

İbn Sina kimya ile ilgili görüşlerini bu makalesinde dokuz kısım halinde toplar. İlk kısımda kimya hakkındaki görüş ve düşüncelerini kısaca anlatır. Ona göre, yukanıda da ifade edildiği üzere, bu sanatla ilgilenenler kadar ona itiraz edenlerin de hataları vardır. Bundan dolayı, o bu konuyu bizzat inceleyip, bir neticeye ulaşmaya çalışmıştur. Bu düşüncelerinin ise "kendi nefsime döndüm ve düşünmeye başladım" cümlesiyle açıklamaktadır. O "bu işin olabilirse nasıl olabileceğini, olamaz ise nasıl olamayacağını" kendisi incelemiş̦tir.

İbn Sina burada verdiği bilgilerde gerek maddenin özelliği ile ilgili olsun gerekse, çeşitli kimyasal işlemlerle ilgili olsun, sık sık şu ifadeyi kullanmıștur; "bu neticeleri kıyas yoluyla daha önce biliyorduk, deney de bunu doğruladı." Bu ifade bize onun bu risalesinde vermiş olduğu bilgileri bizzat yapmış olduğu deneyler neticesinde ulaştığı sonucunu verir. Şimdi burada İbn Sina'nın söz konusu makalesine dayanarak kimya konusundaki çalışmalarını ele alalım.

13 Ahmet Ateş, Ibn Sina ve el-Kimya (meselenin bugünkū hali), Illahiyat Fakültesi Mecmuasi, 1952, say 4, Ankara, s. 47-70. 
İbn Sina, Cabir İbn Hayyan'da da görüldüğü üzere maddeleri kısımlara ayırmışur. Bunlar;

1) ruhlar (ya da uçucu özelliği olan maddeler kükürt gibi);

2) metaller (altun, gümüş, arsenik gibi);

3) bu ikisi dışında kalan yumurta, kıl, dışkı gibi canlının bir parçası ya da onun tarafindan meydana getirilen maddeler.

O bu ayrımı müstakil olarak vermez, ancak çeşitli kimyasal işlemleri yürütürken vermiş olduğu açıklamalar bize bu ayrımı yapmamızı sağlar. Ona göre, her maddenin kendine ait bazı özellikleri vardır. Bazıları karışmaya müsaittir; onlar başka maddeyle karıştukları zaman artık ayrılamazlar, çünkü onun parçaları diğer maddeninkine adeta yapıșmıştur. Bazı maddeler ise, tersine böyle bir özelliğe sahip değillerdir, altun ve arsenik bu ikinci gruba örnek olarak verilebilir.

Aynı şekilde bazı maddelerin eriyebilme özelliği vardır. Onlar alıcıdırlar; nem içerirler. Bunlar buharlaşma sonucu nemlerini kaybederler ve pişerler ve sonunda ısıtma işlemi devam ederse, kül olarak artıkları kalır. Bazı maddeler ise rutubetle o kadar iyi birleşir ki rutubet ondan buhar olarak ayrılamaz; işlemin sonuna kadar yani madde kuruyup kül olana kadar kalır; cesetlerde olduğu gibi.

Bazen bu yanma işlemi küçük zerrelere ayrılana kadar sürer, öyle ki madde tamamen ortadan kaybolur

Bazı maddelerin ise kaynaştırma, birleştirme özelliği vardır; Bunlar adeta maddeleri birbirine kaynaşurırlar. Örneğin yağlar bu tip maddelerdir.

İbn Sina yukarıda özelliklerinden bahsedilen maddelerle ilgili olarak çeşitli kimyasal deneyler yapmış; maddeyi ve onun özelliklerin daha iyi tanımaya çalışmıştır. Bunlar arasında damıtma, süblimleşme, çözme, terkip yapma, yanma ve kalsinasyon ile ilgili yapmış olduğu deneyleri verebiliriz.

İbn Sina çeşitli verilerle işleme tabi tuttuğu terkip ya da maddeyi damıtmıștır. $\mathrm{O}$, canlıdan elde edilen maddeleri örneğin $k a n$, kıl veya canlının bir kısmını ele alır. Bu maddeyi ilkin damıtır, onun su ve yağ kısmını ayırt eder. Hafif atește, imbikte, ilkin o maddenin su, daha sonra yağ kısmı ayrılır. İşlem sürdürülürse geriye sadece kireç kalır. $O$ yağla karıştırılıp pişirilince nişadır elde edilir. 
Buna benzer bir işlemi Razi'de de görüyoruz. Razi saçı alıp, daha önce de açıklandığı üzere, çeşitli yollarla işlemlere tabi tutmuştur. Örneğin bu yollardan birinde, zaçı alıp, onun beyaz, sarı, kırmızı, sularını ayırmıș; bunu tamamladıktan sonra imbik içinde onu ateş üzerine yerleştirmiş; daha sonra onu kör bir imbiğe koyup hafif ateşe koyunca nişadırın oluştuğunu görmüştür ${ }^{14}$.

İbn Sina çeşitli vesilelerle süblimleşme deneyleri yapmıştur. O beyaz boya elde etmek içinde aynı şekilde zaman zaman süblimleşmeye başvurmuştur. Burada cıva kullanmış, cıvayı, bakırla birlikte sirkede pişirmiştir. Daha sonra bu karışımı nemini kaybedene kadar ısıtır. Bu karıșım beyaz bir toz haline gelir. İbn Sina maddenin nemini tamamen bertaraf etmek için işlemi tekrarlar. Öyle ki madde artık yanmayacak hale gelir; sadece beyaz zerreler kalır. Bu işlem bir süblimleşme işlemidir. İbn Sina metninde tarif ettiği bir nevi imbikle bu işi yapar ve aşağı yukarı 7 ila 12 defa tekrarlanan işlem sonunda kurșun ya da tuz tașı gibi bir maddenin şişenin boynunda toplamış olduğunu belirler. Böylece cıva tüm suyunu kaybetmiş ve sabit bir boyama gücü kazanmıştur ki istenen de budur.

İbn Sina bu işlemleri bizzat yaptığını kendinden öncekilerin böyle bir boya bulamadıklarını iddia eder. Ancak Razi'nin konuyla ilgili çalışmaları incelenecek ve onunkiyle kıyaslanacak olursa görülür ki, Razi de beyaz boya elde etmek üzere cıvayı kullanmış ve onu aynı işlemlere tabi tutmuştur, ancak o İbn Sina'dan farklı olarak işlemin başında cıva ile birlikte onunla eşit miktarda kalay kullanmıștır. (onları birbirine karıștırmıștır.) Razi ayrıca, başlangıçta karışımın ne kadar süreyle ısıulması gerektiği gibi yaptığı işlemin ayrıntılarını daha iyi vermektedir. Halbuki aynı ayrıntı İbn Sina'da yoktur. İbn Sina'nın işlemin başında kullandığı bakırı, Razi boyanın daha etkin olmasını göz önünde tutarak, sonradan ilave etmiştir; onu işlemde kullanılan maddelerden biri olarak öngörmez ${ }^{15}$.

İbn Sina'ya göre 'tabiattan çözülebilen, ayrışabilen maddelere tuzlar, gazlar örnek olarak verilebilir.' Yine bu şekilde çözülebilen maddelerin biri de nişadırdır $\left(\mathrm{NH}_{4} \mathrm{Cl}\right)$. Çözülen ya da ayrışan maddelerin asıl cevheri su ve cevherden meydana gelmiştir

\footnotetext{
${ }^{14}$ Seyyid Husseyin Nasr, Science and Civilization Islam, Harvard Univ Press 1968, s.274.

${ }^{15}$ Seyyid Hüseyin Nasr, 1968, s.271-272.
} 
İbn Sina, Razi ve diğer bazı kimya ile meşgul olan kişiler gibi hayvani maddeleri de inceleyerek, onların taklitlerini yapmaya çalışmıştur. Ona göre, eğer hayvani maddelerin analizini yapıyorsak, sıv olarak da hayvani kökenli maddeler kullanmalıyı.

O nişadır $\left(\mathrm{NH}_{4} \mathrm{Cl}\right)$ ve zaç $\left(\mathrm{CaSO}_{4} 5 \mathrm{H}_{2} \mathrm{O}\right)$ karışımını bir şişeye koyup serin bir yerde 40 gün ila 3 ay kadar bekletmiștir. Bu süre sonunda bu karışıma bir tüy atmış ve derhal yandığını tespit etmiştir. Bu reaksiyon o sıvının ne kadar keskin olduğunu göstermektedir.

Muhtemelen burada nişadır ayrışmış ve kuvvetli bir asit teşekkül etmiş olmalıdır ve büyük bir ihtimalle de bu hidroklorik asit $(\mathrm{HCl})$ olmalıdır. Çünkü İbn Sina işlem tam olarak yapıldığında elde edilen maddenin buharlaşabileceğini söyler. Biz hidroklorik asidin kolay buharlaștuğını biliyoruz.

Aynı şekilde Razi'de, de nişadır çözeltisi ile yapılmış deneylere rastlanır. Bunlardan birinde, İbn Sina'nın yukarıda söz konusu edilen deneyine benzer bir deneyle karşılaşıyoruz. Burada o, nişadırla bakır oksidi karıștırıp, damıtur ve bunu 7 defa tekrarlar. Damıtma sonrasında, menekşe yağı ile onu nemlendirir veya bu işi gül yağı ile yapar ve onu bir tarafa bırakır. Buraya kadar bu işlemler, aşağı yukarı İbn Sina'da görülenlerle aynıdır. Razi burada bekletme süresini vermez. Ayrıca daha sonra hayvan tersini nişadırla karıştırır, süblimleşmeye tabi tutar ve o çözeltiyi daha önce bir tarafa bırakılmış olan maddeyle birleştirir. Razi bunun çok sert bir suya dönüştüğünü söyler ki işlemin bu ikinci kısmına İbn Sina'da rastlanmaz. İbn Sina sadece ilk adımda elde edilip, bekletilen terkibini soğuk sularla işleme tabi tuttuğunu ve bununda 30 defa tekrarlandığını ifade eder.

Şüphesiz kimya tarihinde en bilinen işlemlerden birisi, belki de en önemlisi yanmadır. Lavoisier'in oksijeni ve maddenin solunumu prensibini bulmasına kadar bu konuda çok farklı görüşler geliştirilmiştir. Kalsinasyon da bu görüsslerden biridir. Bu görüş daha önce altun ve gümüşün asitle yaptığı reaksiyon ve damıtmadan kurumaya doğru gidilen işlem için kullanılmıştur. İbn Sina bu işlemi bir nevi kireçlenme (kilislenme, calx) olarak kabul etmiştir.

İbn Sina yanabilme ve eriyebilme özelliğini karşılaşurmışur. O diyor ki: 'Yanabilme de; eriyebilme ya da buharlaşma ya da süblimleşme gibi maddenin bir özelliğidir. Yanma sırasında madde ilkin rutubetini kaybeder, sonra pişer ve nihayet kül olarak artı̆̆ kalır. Yanmanın ilk adımı olan rutubetin 
çıkabilmesi için onun maddeden ayrılabilmesi gerekir; daha önce de ifade edildiği gibi, bazı maddelerde, o maddenin özüyle rutubet kaynaşmış durumdadır; buhar halinde rutubet çıkmaz, cesette olduğu gibi ya da eriyik halindeki maddelerde olduğu gibi, ilkin kurur daha sonra kül olur.'

O kalsinasyon uygulaması ile ilgili olarak șöyle söylemektedir: 'Eğer bir maddenin kalsinasyonu, yani yanması mümkünse, onu ateşte ısıtırız. Bazen bu işlem o maddenin çok küçük parçalara ayrılmasına kadar devam eder, hatta tamamen kaybolur.

Burada muhtemelen İbn Sina onun tamamen gaz haline dönüștügünü söylemek istiyor. Onun kalsinasyondan ya da kalsine olmaktan ne anladığını, söz konusu risalesinden bir örnekle inceleyelim; 'Cisimler bazen nişadır $(\mathrm{NH}, \mathrm{Cl})$ ve sirkeyle karıştrrılır ve ögütülmüss tuz ve nișadırdan kükürt gibi maddeler kabul edebilecek hale gelene kadar isitilir. Daha sonra bu beyaz zerreler içine tuzlu su karıştırılıp, kütle haline gelene kadar ocağın üzerinde isithlir.'

Burada isınma, daha çok parçalanma, ayrılıp başka maddelerle yeni tepkimeler meydana getirme gibi anlamlandırılabilirse de, metnin devamında onun kalsinasyonu daha farklı düşündüğü ortaya çıkar. O 'sarı boya istendiğinde zaç ve kükürt veya yumurta yağı birbirine karıştırılır, ısıtma işlemine karışım kızarana kadar devam edilir. Böylece mevcut madde en küçük zerrelerine ayrılır', demektir.

Yukarıdaki açıklamalardan İbn Sina'nın kalsinasyonun daha çok kızarma, kızıllaştırma ve daha sonra küçük parçalarına ayrılma olarak düşündüğü sonucu ortaya çıkarılabilir.

İbn Sina kimyayı bir sanat olarak kabul etmiştir. O, daha öncede belirttiği üzere, kendinden önce bu konuda çalışanların verdiği bilgiye itiraz etmiş ve konu hakkında en sağlıklı bilgiyi kendi yaptığı deneylerle elde etmek istediğini ifade etmiştir. Bilindiği üzere, o devirde kimya ile uğraşanlar alun ve gümüşü daha az değerli maddelerden elde etmeğe çalışmışlardı. İbn Sina yapmış olduğu deneylerle ve de kendi deyimiyle kıyas yoluyla, altun ve gümüş renginde boyalar elde edip edemeyeceği konusunu araşturmıştur. Ancak söz konusu el-Kimya Risalesi'nde de görüldüğü üzere, onun altun ya da gümüş yapma çabalarına rastlanmaz.

İbn Sina gümüş rengi beyaz boya elde edebilmek için temel madde olarak cıvayı kullanıyor; altın rengi sarı ya da kırmızı boya için ise temel madde 
olarak gümüşü kullanıyor. Ancak gümüş karıştırdığı diğer maddeler, örneğin kükürt tuzları ya da bir başka madde, gümüşün kararmasına neden oluyor. Burada onun gayesi altın ve gümüş renginde sabit, altun ya da gümüşe karışabilen, fakat onlarda herhangi bir değişiklik meydana getirmeyen bir madde elde etmekti. Neticede çeşitli deneylerden sonra, o istediği özellikleri taşıyan beyaz ve sarı boyayı elde ediyor. Beyaz boyayı bakırla birlikte pişirip nemini uçurmak suretiyle elde ediyor. Bu boya muhtelif işlemler sonunda elde edilen beyaz yanmayan bir boyadır. Ancak o bunun gümüşle eş değer olduğunu ya da bu muamelelerle gümüşe benzer bir madde elde etmiş olduğunu hiçbir zaman söylemiyor.

Kırmızı ya da altun rengi boya için ise İbn Sina temel madde olarak gümüşü kullanıyor ve ona cıva, kükürt, arsenik veya bir yağ katyyor, fakat en iyi neticenin kükürtle elde edildiğini söylüyor. İlkin kükürdü suda tekrar tekrar pişiriyor ve bu işlem suya artık boya çıkmayana kadar devam ediyor. Sonra bu sular toplanıyor, süzülüp, damıtulıp kırmızı boya elde ediliyor. Eğer boya siyah olursa pişme sırasında yanmış olduğu neticesine varıyor. Kırmızı renkte olan boya turunç ekşisiyle muamele edilip, pişiriliyor. Sonuçta elde edilen boya sarıdır. Bu altun rengi bir boyadır, fakat altuna benzer bir madde değildir.

İbn Sina burada beyaz ve sarı boyalar elde edilecek başka yollar da önermektedir. Hatta o, bazı hayvani maddelerden de bu boyaların elde edilebileceğini ifade etmiștir.

İbn Sina makalesinde altun ve gümüş elde etmek için yine gümüş ve altuna ihtiyaç olduğunu söylemiştir. Ona göre, altundan altun yapmak için ona bakır ve kızartmak için de zencefre (cıva sülfür) karıştırılması gerektiğini; gümüş için ise beyaz kurşun (üstübeç) kullanılabilir. İbn Sina'nın yaşadığı devirde ve daha sonraları biz bu tip uygulamalarla karşılaşıyoruz. Hatta bugün de altun ve gümüşe başka madenler karıştırılmak suretiyle düşük ayarda altın ve gümüş yapıldığı bilinmektedir.

Ona göre, bütün mevcut maddeler dört ana unsurdan meydana gelmiştir; toprak, su, hava ve ateş. Bazı maddeler bunlardan birini; bazıları ise dördünü birden içerir. Örneğin sarı boyalar dört unsuru da içerir. Beyazlar ise su, hava ve toprak içerir. Cıva su, yağ, hava, kırmızı ateş ihtiva eder. Daha önce de belirtildiği üzere, her maddenin nemlilik, kuruluk, sıcaklık, soğukluk, eriyebilme, yanabilme, çözülebilme, buharlaşma v.s. gibi özellikleri 
vardır. Daha önce de zikredildiği gibi, her madde kendi özelliğini korur ve eğer bu özellikleri değişirse artık o madde kendisi olmaktan çıkar ve bozulur. Bundan da anlaşıldığı üzere bu değişim (transmutation) tersini kabul etinez. İbn Sina maddenin bu özelliklerini göz önünde bulundurarak, sabit, ruit. siz, yanmayan başka bir maddeye karıştırıldığında onu bozmayan boyalar elde etmeğe çalışmıştır. Beyaz boya için bu terkibi şöyle verir: cıva, kükürt, beyazlatulmış arsenik ve üstübeç (beyaz kurşun). $\mathrm{O}$ buna el-iksir der.

Sarı boya ise, cıva, beyazlatılmış kükürt ve kireç taşından meydana gelir. Ona göre, bu ikisi, yani beyaz ve sarı boya birleşince, tam iksir meydana getirirler.

İslam dünyasında İbn Sina gibi, birçok filozof ve bilim adamının aynı şekilde el-iksirle ilgilendiği görülür. İbn Sina devrinde ve daha sonraki dönemlerde de İslam dünyasında filozof ve bilim adamları kimya ve simyayla ilgilenmişlerdir. Ancak daha çok simyanın ağırlık taşıdığı görülmektedir. İslam dünyasının seçkin kimyagerlerinden biri de Ebu'l-Kasım el-Iraki'dir (XIII. yüzyıl). O simya konusundaki eserleriyle, büyük şöhret yapmışur. $\mathrm{O}$ Cabir b. Hayyan'ın öğretisine tamamen sadık kalmış; onun gibi maddenin dahili ve harici özelliklerini tespit etmiştir ${ }^{16}$.

Buna tiave olarak, İslam dünyasında simya ile ilgilenip eserler veren birçok alimin adı sayılabilir. Örneğin Ebu'l- Kasım al-Kuş Hayri Kimya-ı Saadet, Ebu Meslama el-Macriti Ratbat el-Hakim adlı meşhur eserlerini vermişlerdir.

İslam dünyasındaki bu çalışmalar, XII. yüzyılda Avrupa'da başlayan çeviri faaliyetleri sonunda, diğer bilimsel eserler gibi, Arapçadan Latinceye çevrilmeye başlamıştır. Simya konusunda ilk çeviri Robert Chester tarafından 1140 tarihinde yapılmıștır. Bu arada bilim ve felsefeyle ilgilenen birçok düşünür kimya hakkında fikir beyan etmekten geri kalmamışlardır, hatta bazıları daha da ileri giderek, konuyla daha yakından ilgilenmişlerdir. Örneğin Albertus Magnus (1193-1288) her ne kadar simyanın bilim olmayıp, adeta bir bilim taklidi olduğunu iddia etmesine rağmen, De Mineralibus adlı eserinde kimya ve simya ile ilgili olarak geniş bilgi vermekten geri kalmamıştır. O, bu konuda İslam dünyasında yapılan çalışmaları biliyordu; kendisi de altın yapmay denemiştir.

${ }^{16}$ Seyyid Hüseyin Nasr, 1968, s. 278-282. 
Albertus Magnus İbn Sina'dan alıntılar yapmıştır. İbn Sina'ya ait olduğu iddia edilen De Anima adlı esere işaret ederek, onun teorisi, yani bir cevherin diğer bir cevhere dönüşebileceği görüşünü reddettiğini ifade etmiştir. Ayrıca, Albertus Magnus'un De Alchimia adlı zekice kaleme alınmış bir simya kitabının da yazarı olduğu söylenir ${ }^{17}$.

Avrupa'da bu dönemde simya ile ilgilenip, İslam kimyacılarından özellikle İbn Sina'dan etkilenenler arasında Robert Bacon (1214-1292) da zikredilebilir. O İslam dünyası yoluyla Çin'den Avrupa'ya aktarılmış olan barut hakkında bilgi vermiştir. Ayrıca yine o, tuzlar, odun kömürü ve kükürt konusunda da araşturma yapmıştur. Birçok simya eseri Bacon'a atfedilir. Bacon, İbn Sina'nın olduğu söylenen De Anima'nın bir özetini yapmıștır ve eserlerinde onun etkisini hissetmek mümkündür.

Bacon'un yanı sıra Villanova'lı Arnold, Raymond Luly ve birçoklarını burada saymak mümkündür. Ancak kısaca ifade edilecek olursa, her ne kadar bazı yazarlar İbn Sina'nın kimyaya karşı olduğunu iddia etmişlerse de, İbn Sina kimya ile ilgilenmiş, daha önce verilen bilgileri denetlemiş ve kendi elde ettiği sonuçları bize Kimya Risalesi başta olmak üzere, bu konuda yazdığı eserinde sunmuştur. Bu eserler sadece İslam dünyasında değil, daha önce de belirtildiği gibi, çeviri faaliyetleri neticesinde bilimin filizlenmekte olduğu Batı dünyasında da etkin olmuştur.

\section{(Metin)}

\section{Risalat Fi Mestur İlm el-Sınaat ${ }^{18}$ Ibn Sina}

Bağışlayan ve Yargılayan Tanrı'nın Adıyla,

[Bu makalenin konusu olan simya hakkındaki tartşsma] benim ve eşŞeyh, es- Seyid, el-Alim, Ebi-l- Hasan, Sehl b. Muhammed el- Sehli arasında geçti. Tanrı onun gizli sanattaki (simya) bilinen feyzini, şerefli ve yüceliğini daim kılsın. Benim düşündüğüm, meylettiğim ve ümit ettiğim şeye ulaşmak için o delil gösterdi ve burada ben 9 kısım olarak [o konudaki düşüncelerimi] açıkladım.

17 J.R. Partington, A Short History of Chemistry, 1957, s.36-37.

18 İbn Sina, Risalat al- İksir, açıklama ve metin Ahmet Ateş, Türkiyat Mecmuası, c. 10, yıl, 1953. s.35-53. 


\section{Birinci Kısım \\ Bu Sanatla (Simya) İ̀ili Bütün İșlemler Hakkında}

Allah Seyh' ül- Reis Seyid'i daim kılsın. Dikkatle yapılması gereken doğal işlerde bakışını keskinleștirsin. Dünya ile ilgilenenlerin ürettikleri fikirlerden biri [simya ile ilgili] işlemleri ile ilgili idi. Onların (simyanın işlemleri) çoğu fazlahılıklarla ilgili olup, gereksizlik, itiraz edilen ve sahte olan işlemlerden oluşmaktaydı. O (simya) yetersiz olan ilimlerdendi. Onlarla (simya işlemleri) ilgilenenler hilekar ve düzenbaz diye kabul ediliyordu. Sanatta her iki grubun da gidişini bilmek gerekir. Genel olarak bu konudaki kitapları sanatla ilgili diye kabul ettim. Bütün sanatlanın gayesi olan kıyasın onda olmadığını ve ondaki şeylerin çoğunlukla hezeyan nevinden olduğunu belirledim. Kitaplarda onlarla ilgili tenkitlere baktım ve itirazların zayıf, yetersiz, çelişkili, ve çocukça (basitçe) kıyaslı ve sanat gibi eksiksiz olduğunu gördüm. Düşüncemi topladım ve bu işin ne olduğunu, nasıl olduğunu ve şayet olmadı ise nasıl olmadığı konusundaki fikirleri ele aldım.

Altının renginin gümüs rengine veya bakırın renginin gümüş rengine döndürmenin (renklerini açmak) mümkün olup olmadığını inceledim. Gerçekte beyaz olan (rengi açılmış olan) kızıllaşt. Beyaz açılıp, açık renk oldu ve bu çalışmalardan biz, taş gibi katı cisimleri açmak için yapılan karışımı yumuşatmak ve değiştirmenin mümkün olmadığını ögrendik.

İşlemlerin başında erimesi mümkün olmayanı yumuşatıp, akıcı hale getirdik. Eğer eridiyse, kızıllaşan rengi büsbütün açılmadı veya bizim istediğimiz beyaz renge erişmedi. Şüphesiz ki, eğer renk açma işlemi ateş üzerinde yakılarak yapılsaydı olmazdı, bozulurdu veya eğer ateşte yakılmazsa, faaliyeti durmazdı, ancak uçup giderdi ve faydalı olmayıp harap olurdu veya o yakılmayınca ve uçup gitmediğinde ise, ancak ona nüfuz edilmediğinde veya karışılmadığında, bu durumda olacağı için, yararlı olmazdı. Onun içine nüfuz edilir veya karışlırsa, ancak o zaman mevcut halini koruyamıyor ve saBit kalmıyordu.

Ancak kaçıcı ve uçucu olduğunda veya parçalara ayrıldığında, yani kabaca kısımlardan meydana gelmiş haldeyken faydalı değildi veya kısımlara ayrılmamıştı. Ancak gümüş, altın gibi yanmaz hale getirilemez. Gümüş kükürt gibi yanar. [O], altun gibi saf olan, faydah olmayan gümüşten arıtıldı yahut da yanmayan gümüşle bakır yanmaz hale getirildi ve bakır ve kurşun ve diğerleri gibi yakıldı. 
Cisimleri erimiş; yanmış olanlardan onları (cevherlerini) ayırt edebilmek için cisimlerin kısımlarını bırakıp, sıcak yanmış şeyleri toplayıp, yanmadan erimiş olanları cisimle karıştırarak daha beyaz veya daha sarı olacak şeklide boyayı açmağa çabaladık.

Genel olarak, bu fiil için basit ilaçlarda çare aradık. Akkar (bir nevi ubbi bitki) ve bununla yapılan ilaçlardan fazla bir sonuç elde edemedik ve ancak bu bitkiyi kullanmak bizi sarst;; o vücutta nöbet yapt;; bu onun özelliği idi. Kırmızı kükürt (kibrit-i ahmer) Fergana'dan başka yerde yoktur. Bundan başka mevcut ilaçlardan biri zırnıh-ı beyaz'dır (beyaz arsenik). Bu iksirin etkisinin titretici (sarsıcı) olduğu zannedilmektedir. Şüphesiz, bu özelliği onu bilen kişiler tarafından pek de bilinmemektedir. Bu sonuncuyu kendi çalışmalarımız sonucunda belirledik.

Ateşin bozamayacağı bir boya elde etmek istedik. Karışmış cevher eridiğinden dolayı karışmış ve yumuşamıştur.

Bazı mizaçtaki cevherler ateş üzerinde zorla, sabitlenmiş, bağlanmıştur. Bazısında ise şöyledir: bir cevher vardır ki onda mevcut olan maddeler ateşte ayrılmaz, ancak kendi içindeki bir madde vasıtasıyla boyanır. $\mathrm{O}$ şey boyadır ve ondaki cevherle karışmış durumdadır ve yumuşayan cevherle birlikte yumuşar ve donan, katılan cevheriyle katılır. Beş şeyde bu özellik vardır ve biz onu kendi gayelerimiz doğrultusunda değiştirebiliriz.

\section{İkinci Kısım \\ (Boyanın Elde Edilmesi Talep Etme Hakkında)}

Saflaşturmayla ilgili olarak, beyazlanmış cıvayı bulduk ve onu beyazlatan saf cisimlerle bağlanmış olduğunu belirledik. Hatta, [o] zaçla yandaş oldu ve asit şeklinde pişirildi. Onun içine, beyazlığın nüfuz etmesi uzun zaman almadı; onun görünmez olması, uçması çok vakit almadı. Onun içi gümüş gibi idi ve hatta o bana şu kanaati verdi. Eğer cıvayı çok koyarsak, [karışımın] etkisi artar ve daha etkin olur. Ancak ben bizim onu ateşten uzak tutarak elde tutabileceğimizi belirledim.

Her şeyi birbirine karıştırmamak lazımdır. Ancak onu [boyalarla] karışturmak, mezcetmek istiyoruz. Bu iyi olur. Şüphesiz o ateş üzerinde yakılmaz. Muhtemelen [böyle yapılırsa] buharlaşır. Biz onu yanmaktan korumakla yetiniriz. Biz biliriz ki, eğer o, ateşten uzak olursa, o zaman onun geri kalanı eriyiklerle kendi hali üzere karışır ve biz onun boşalan (uçan) 
şeylerin ilki olduğunu görürüz. Ondan sıvının yok olduğunu, öyle ki yayılma, parçalanma ve toz haline gelmesinin mümkün olduğunu da belirleriz. Bunlar olsa bile, onun şeylerle toz haline gelmeğe başladığında ve şeylerle arasında dönüș başladığında hayat oluşmaz ve o ölür ve biz onu sulandirırız.

Burada amaç onu karışturmaktur. O kendiliğinden nimet sahibidir. Kesinlikle ateşte yanmaz. Ateşte buharlaşır. Yanma işleminin zahmetinden bizi kurtarır. [Bu işlemlerden] öğrendik ki, eriyenler karışturılınca kendi renklerinde, beyaz halinde kalır. Gördük ki, ilk şey kurutulunca, kendiliğinden sıvı halin yok olması ile parça parça olur veya toz hale gelir. Hatta başka şeylerle karıştırmakla ona can verilemez ve ölür. Şayet ihtiyaç olduğunda ve karışturmak istersek ve sularla karıştırırsak, [sularla suladığımız şeylerin halini alır [canlanır].

Birleştirmek ve karıştırmak gerektiğinde, bazen sularla suladığımız şeylere dönüşür. Bunun yolu ateş üzerinde bir pişirmektir. [Böyle yapıldığında] cisim akıcı parçalara ayrılır ve o toz haline gelir. Bundan sonra, akıcı bir şeyin meydana gelmesi mümkün olmaz; kuru olarak kalır. Ondan kuruluk çıkar. Özellikle bundan gayemiz ilaçlara karıșturmak ise, bunun hepsinin uçması mümkün olmaz. Kuruluk [özelliği] ve cıvadan ilacın rutubeti kaldırılır. Kurusu bir yere toplanır; [çökelti oluşur]. Kesinlikle tekrar akıcı hale gelmesin diye, [nemi kaldırmak için] birçok defa biz bu işlemi tekrarlarız; öyle ki, onda yanacak bir şey varsa, işlem sırasında yanar, ondaki sulu şeyler kaybolur ve sonuçta öyle bir şey kalır ki, artık yanmaz ve kuruluk kalkar; beyaz zerreler kalır; artık yanmayacak hale gelir veya kendisinde yanma olmayan bir birleşim olarak kalır. Bu durumda buharlaştırmaya ihtiyacımız olur ve bir ölçüde [bu] işlemi uygularız.

Basit ilaçlar da tam anlamıyla bu işlemin olup olmadığına baktık. Akakir (bir nevi tubbi bitki) ve edviyelerden bize ulaşan şeylerin bu etkilere sahip olduğunu gösteren bir șey bulamadık. Ancak bize gelen bilgiye göre bir bitki vardı; kırmızı kükürt (Fergana kükürdü) ve beyaz zırnıkta (arsenik) uyguladık. Bunların mevcudun dışında bu işlevi vardır. Ancak bizim zannettiğimize göre, bu konuda herhangi bir bilim ehlinin bilgisi mevcut değildi. Bu işlemi kendimizin yapması gerekti. Ateşin bozmayacağı sert ve iyice sıkıştırılmış bir cevher ve bir boya alacağız. Onları ateşin üzerine koyacağız. Bunları birbirine karıştıracağız, ancak onlardan elde edeceğimiz cevherin ateşte parçalarına ayrılması gerekir. Bu cevher, kendisindeki boya 
ile boyanır ve cevherle karışır. Burada yumuşak cevher kaynaşır, ancak cevher daima sabit kalır. Bu beș șeyi elde ettiğimiz zaman hedefe varmış oluruz.

Boyanın elde edilmesinde, eğer cıva kullanılmışsa, beyaz ise, onun (terkibin) beyazlaşmış olduğunu gördük. Beyazlaşturılınca cisimlere yapışır; diğer cisimlere nüfuz eder, onların içine girer. Bu terkip bakırla sirke içinde pişirilir. İlaçların bu beyazlığın (terkibin) içine nüfuzu durmaz, ta ki gümüs gibi içi ve dışı beyazlaşana kadar bu işlem devam eder. Bu durumda boru şeklinde uzun bir kap alırız. Bir başka kap daha alırız; onun alt kısmı yuvarlaktır; tümsek şeklindedir. Elimizdeki maddenin çoğunu bu iş için hazırlanmıs ocağın üzerine koyarız, öyle ki boru şeklindeki kabın başı yuvarlak kabın çukuru ile uyuşur ve böylece onun ağzını kapatır ve böylece yuvarlak alth kabın üst kısmında, onun içine dökülen cıvanın dumanı birikir. Cıvayı döktüğümüz yerin üzerindeki [boruda] bir delik vardır. Dumanın biriktiği tahmin edildiğinde bu delik açılıp, oradan duman çıkıp çıkmadığı ve dumanın bitip bitmediği kontrol edilecektir. Bu delikten bakarak, dumanın çıkıp çıkmadığı belirlenir.

Onu çıkardığımızda yanan nesnelerle öğütüp, toz haline getiririz. Onlar diğer benzeri şeyler gibi, kuru tuz gibi ya da gaz gibi bir hal alır.

Şayet cıvanın onunla (bakır) çok iyi karışmasını istersek [terkibi] orta ateşte kızarurız. Bu işlemi çamurdan pişirilerek yapılmış tencerede yaparız. O tencereyi hikmet çamuru (kara çamur) ile sıvarız; kuruturuz ve firına koyarız. Daha sonra, biz cıvanın nasıl öldürüldüğünü ve hikmet çamurunun ne olduğunu ele alacağız. Cıvayı piştikten sonra, toz haline getiririz, onu yükseltme derecesine çıkarıız. Bu tencerenin adına hikmet tenceresi denir. Terkibi tencerede birkaç defa aynı muameleye tabi tutarız; her işlemden sonra, karıșımı inceleriz ve onu aynı şekilde eski haline döndürürüz. Bu işlemi terkibin rengi beyazlaşıncaya kadar birkaç defa yaparız. Belki de bu işlem 7 defada gerçekleşir ve belki de 12. defada [bu neticeye] ulaşırız; gaye bu sonuca ulaşmaktır. Belki de sonuncusunu hikmet çamuruyla çamurlanmış bir şişede ihtiyatlıca bir şekilde yaparız; nemini aldıktan sonra tüp şeklindeki kabın başını bağlarız. Bundan sonra terkibi çıkartırız, hatta bazen terkip kabın boynunda kurşun gibi ve bazen de toz taşı gibi toplanana kadar işlemi devam ettiririz.

Bu bilimsel sonuçlar deney ve uygulamalardan sonra ortaya çıkt. Bütün bunlardan amaç cıvanın kurutulmasıdır. Bu işlemleri yaptığımız zaman boya 
gücü kalıcı hale gelir ve boya ve nüfuz ediciliği açısından [bu durum] uygun olur, öyle ki onun [rengi] saf gümüşün renginden farksızdır; hatta boya bakımından daha doymuş ve beyazlığı daha tamdır. Ancak bu sonuç, deneylerden önce ayrıntılarıyla ve kesin olarak bizce biliniyordu. Biz, ihtiyacımız olan şeylerden ayrı olarak, beyaz boyayı elde ettik.

Kırmızı boya [ile ilgili olarak yaptığımız araşturmalarda] ise ilk sebeplerde kızarmış bir şeye rastlayamadık, ancak bu arada gümüşe nüfuz eden diğer bazı şeyleri bulduk. Gümüşün içine giren bu şeyler onu renklendiriyor ve onu renkleriyle siyaha boyuyordu. Onu renklendiren şeyleri de bulduk; sonra kükürdü gördü. Gümüş onun buharına tutulunca biraz sararmaktaydı; üzerine konduğu [maddeyi] karartyordu.

Eğer kükürt eritmeden gümüşün üzerine konursa, onu yakıp köreltir; rengini kaçırır. Biz biliyoruz ki yakma ile siyahlaşan her şeye ancak beyaz kanalıyla gidilir; yeşilden gidilmez; hatta sarılık ve kırmızılık yakmaktan da gidilebilir. Bundan dolayı, duman, havada çözüldüğünde havayı yeşillendirmez, onu kızıllaşurır. Biz siyahlaşan gümüşten, hassas bir işlemle sarı boyayı çıkarmamızın mümkün olduğunu anladık.

Yine öğrendik ki, kendisinde yanma kabiliyeti olan şey pişirilince ondan ayrılan (çözülen) kendisindeki ateş gücüdür. Çünkü o diğer unsurların güçlerinden daha hafiftir ve buharlaşmada önceliğe sahiptir. Yaptuğımız analiz sonucunda şu neticeye varırız: kükürtten veya arsenikten veya yağlardan gümüşü siyahlandıranları ayırmak mümkündür. Çünkü maden grubunun en üstünü olan gümüşü siyahlandırmak için kükürt veya yağlardan biri ile cıvayı kullanabiliriz. Bu durumda kükürt madenlerin en iyisidir. Burada da aynı yöntemi kullanırız; onu suda mutedil bir ateşle pişiririz, öyle ki ateş gücü onu hararetlendirir ve ateş onun gücünden çıkar. Kükürdün cevherinden bir şey yanmaz. Kükürt renginden bir şey fark etmez; kükürt boyama kabında bir șey kalmaz. Biz, daha sonra zikredeceğimiz gibi, sadece boyanın açığa çıkması için kükürdü gerektiği üzere, bıraktık. Bu işlem ancak, birkaç defa tekrarlanır ya da güneşte veya sıcak külde kaynatmamak şartıyla tekrarlanır. Bu birleşme ne kadar şiddetli olursa, bozulmaktan ve ayrılmaktan o kadar uzaklaşır. Ayrıca, her boyayı hararet eritir ve onda en aşağı derecede ve en az seviyede bir keskinlik olmadığı sürece [işlem] tatlı suyla (normal suyla) yapılırsa yeterli olur. Bu işlem daha kolay yapılmasını sağlar. Belirleyebildiğimiz kadarıyla, fikir ve deneye dayanarak bu suyu nasıl yapmamız (distile etmemiz, damıtmamız, saflaştırmamız) gerekir? Biz kükürdü suda tekrar tekrar pişirirsek su her boyandığında ve kızıllaştırdığında suyu değiştiririz, yani suyu yenileriz öyle ki, hiç boya kalmayıncaya kadar işlemi 
tekrarlarız. Sonra suları toplarız. Suyu damitriz ve altunda bir boya birikene kadar hafif ateşte ısıturız. Eğer kırmızı olursa bileşimi elde etmiş oluruz.

Eğer terkibin rengi siyahlaşmışsa, pişirirken yakmış olmanız gerekir. Eğer kırmızılaşırsa bu bileşimi alırız. Bu terkip yoğunlaşurılmış sirke gibidir. Soğuk sularda ekşimiş ayran usaresinden de alınarak pişirmeye devam ederiz. Keşk unundan ekşimiş kabarcıklar alıp işleme devam ederiz veya turunç ekşisi suyunda yahut da diğer benzerlerinde tekrar tekrar pişiririz. Onun ateşliliği kırılıncaya ve işlem zayıflayıncaya kadar bu işleme devam ederiz. Böylece, bu işleme terkip yakma gücünü kaybedene kadar da sürdürürüz. Bu durumda onda sarılık ya da siyahlık kalır. Ancak onun siyahlık ve sarılığı çok azdır. Bu etki tam anlamıyla ısıtıldığında kalıcı hale gelir. $\mathrm{O}$ zaman boyayı elde ederiz. Onu neyle karışturmak istersek karışmasının kolaylaşması için nemliliğe ihtiyaç duyacağı. Özellikle güzellik ve düzgünlüğü temin etmek için bu yolu izleriz.

Cıvanın zencefre gibi kızıllaşması mümkün olur; yanan şeylerin yanmaması için ek işlem ve alınan tedbirlerle kızarır. Bu demektir ki, bu ek tedbirler onun yanmasına mani olmuyor. Kızıllaşmış cıva zikrettiğimiz gibi mumlanır ve çözülmeğe tabi tutulursa, akıcı bir kırmızılık kazanır; kendisi de boyama özelliği kazanır. Zencefrede olduğu gibi ve kendisiyle uyuşan ve karıșan boyada olduğu gibi, kendisi de boyama kabiliyetine sahiptir, ancak o boya yanıcıdır. Zencefre ise yanıcı değildir. Kükürdün cıvayla tam anlamıyla birleştiğini ve bu birleşimin arttığını bildiğimizden dolayı, bizi bu yola götüren zencefredir. Civa ile aynı miktarda veya boya biraz daha az olmak üzere, boya ve cıvayı karıştırdığımız zaman eritilen cıvanın kızıllaştırılmıș olması gerekir. Çünkü o, karışım, zencefre de olduğu gibi kızıllaşır. Ancak kızıllaşması mümkünse, o terkip daha üstündür. Bu ikisini iyice gübrenin içine gömeriz.

Bu durumda kızıllaşurılmıș ve beyazlașturılmış boya elde edilmiş olur. Bu temel unsurdan biridir. En iyisini Tanrı bilir.

\section{Üçüncü Fasıl (Çözeltiyle Karışan Cevherler)}

Üçüncü unsurumuz ise çözeltiye karışan cevherlerle ilgilidir. Cevherin çözünen cinsten olması gerekir. Yokladığımıza, aradığımıza, muayene ettiğimize dayanarak, çözeltiye atılan şeyin ne olduğunu arayalım. Ona karışturılan ve ona konan şeyi bozulmamış olarak bulmadık. $\mathrm{O}$, kesinlikle 
işlem sırasında değişiyordu ve bozuluyordu. Böylece, esas maddeye katulan şeyin, onun içine girdiğini, onunla karıştığını anladık. Ancak madenler cinsinden karışanlardan kükürt ve arseniği belirledik. Bunlar ateşten kaçan, birleşmeyen ya da çok az birleşebilen, ancak ona yapışan, takılan cinsten de olmayan; bunlara uygun olmayan maddelerdi, hatta yapışsın ve onun üstünde eğreti durmasın diye onların birleşme özelliklerini geliştirmek için yollar aradık, ama bir yol bulamadık.

Yanmanın sebebini, buharlaşan maddenin ateş tabiatına süratle dönüşmesinde bulduk. Yapışma sebebini çözünmekte ve sonra maddelerin şekil ve tabiatta birbirlerine yakın oluşlarında olduğunu belirledik. Onların doğal köklerine baktık; çözünme illeti akıcı, nemlilik, yeryüzünden alınma kuru parçalarla karışı halde olan ter idi. Ateş bunu ayırdığında o madde içinde harekete geçiyordu. Maddeler ona öyle karışmıştır ki onların ayrılmaları mümkün değildi. Buharlaşma illetini kuru parçalara karıșmış olan ancak çok fazla karışmamış rutubetle bir arada bulduk. Aksi taktirde bu rutubet ondan yükselip çıkardı. Yanma illiyetini (nedenselliğini) herhangi bir rutubetin cismin kuruluğu ile karışarak pişmiş olmasında bulduk; hatta öyle ki bu cismin bu kuruluğa karışmasından ve arızı hararetten yararlanmasından ortaya çıkmış olduğunu belirledik.

Burada (yukarda işlemde) ateşe benzerlik vardır. Hatta ateşin faydası olmuştur. İşlem mevcut rutubetten yardım alarak, işlemde istenen zamanı kazanmıştur. Bu durumda [ateşin gıdası] herhangi bir cismin parçalarını buharlaşmadan veya buharlaşmayla ateş cevherine çevirmeden, ateşe güç kazandırmaktadır. O, ateşi besler; kuvvetlendirir; onun gıdası ve gücüdür. Artığı kül olarak kalır. O ateş olarak kurtulur. $O$, yanan cevherdir ve buharlaştuğında doğrudan doğruya aleve dönüşür. Ancak bunun nasıl olduğunu ve uzak ve yakın sebeplerini araştırmak, bu kitaba sığmayacak bir konudur. Ancak deney bunu gösterir. Bunun sonucunda, rutubetin yanmadığını belirleriz. Hatta ve ancak sıcaklığın ona ilk isabet ettiğinde yanmasında söylenen sonuçların doğruluğu ortaya çıkar. Şayet rutubet bir şeyde gizli ise bu cevher buharlaşan şeyden değilse, eriyen cisim ya da cesetlerde olduğu gibi, kuruyan kül haline gelinceye kadar o şey yanmaz. Daha sonra kendisinin aslında hararet olan veya hayvanın cismindeki maddede karışma gücü varsa veya olursa, nem kurusuyla pişer, hatta yapışkan hale gelir, yağ olur ve yanar. 
O yağ olmazsa ancak şiddetli kurulukla karışmıştur ve bununla beraber, çok az yağlılıktan az yağlılığa dönüşür. Onun yakıcı gücünden ve yăğlı̆̆ından rutubet kalmayınca kurtulduğunu gördük.

Rutubet zikrettiğimiz yolla erir ya da yapışan hale gelir. Büyük bir ihtimalle bu tip cisimlerdeki rutubet kendisindeki şiddetli kuruluktan kurtulamaz, hatta öyle ki, ateş onu buharlaşmaya doğru tahrik ettiğinde, kuruluk artık çoğunlukta olduğunda, rutubetten kurtulmaz. Ancak, camda olduğu gibi, ondan rutubet adeta akar ve erir.

Rutubet çoğunluktaysa, buharlaşır, alevlenir ve yanar. Sonra biz nasıl buharlaştığını görmek için denediğimizde buharının duman olduğunu gördük. Biz onda kuruluğa karışan bir sululuk olduğunu belirledik. Ondan sadece su olan kısım çıkmaz. Daha sonra, bunu deneysel olarak araşurdığımızda, kuruluktaki ıslaklı̆̆ı çoğu buharlaşma ile azaldığını belirledik. Bizce sabit olduğuna göre, [bu madde] buharlaşmayla bozulmayacağı gibi miktar olarak da eksilmez.

Onun rutubeti kuruluğuna karışmıştır. Biz onu ateşe tutarsak, yanma özelliği kalkar, ama yapışma özelliği kalır. Ondaki yanma özelliğini yok etmeyi düşündük ve bunun için birkaç yol öngördük. Birincisi, [onun] yanan ve kurutulan şeylerle birlikte ateşe tutulmasıdır ve rutubetin yükseltilmesi, yani kaldırılmasıdır. Kesinlikle [kaçınılmaz bir şekilde] yanan yanar, yanmayan sağlam olarak kurtulur. Şayet hala yanan şey bulunduğu takdirde, bu işlemi tekrar ettiğimizde, sonunda buluruz ki, yanmayla karışmamış olan, yanacak bir madde yoksa beyaz bir madde kalır. O gümüşle karıștırınca gümüșü yakmadığı gibi bozmaz da. Bu konunun burada açıklanması ve belirtilmesi uzun olacaktur, fakat kıyaslarla elde edilen sonucun kesinliği bizce görülmüştür. Bu işlem maddenin içindeki nüfuz etme ve yapışma özelliğini yok etmez ve bu işlem rutubetle daha kolay tamamlanır.

Ancak yakmak ve yanmak için maddede rutubet varsa, o [cisme] karıştığında ve yandığında yakar ve rutubetli özü (cevheri) bozar. Biz o rutubeti tamamen kaldırdığımızda [cevher artık] yanmaz; fazla olan rutubeti çözüp, ondan aturırız. Fazla olan ve yanan rutubet bozulur ve uçar.

Kuruluk sınırında karışan rutubet geriye kalır. Bunlar sabit rutubetlerdir. Bundan dolayı onlar ateşte yağ olarak erirler. Biz bu rutubetin yapışkan olarak, nesnede kalıcı olduğunu deneylerde belirledik. 
Bununla ilgili olarak, eriyiğin içinde kaldığında, ona bir şey karışurırsak veya kabın ağzını kapatursak, beyaz olmayan şeyin ondan kurtulmadığı için beyazlaştığını bulduk. Bu işlemin yapılabildiğini belirledik. Biz bunu denemeden önce, kıyas yaparak öğrenmiştik. Deney bu görüşü doğruladı. Cisme her beyaz nesne karıştuğında karıştırıldığı şeyi beyazlaștırır; biz onun karıştırılan nesne ile ilgili olduğunu bulduğumuz zaman istediğimiz [şey de] gerçekleşmiş oldu. Belki, ancak ateşte veya suda pișirdiğimizde, ateş ona giriyordu, ancak biz onu, nemlilik ondan ayrılıncaya kadar çıkaramadık.

Bu yolla da aynı neticeye vardık. Kuruluğa galip olan rutubetin çoğu buharlaşır, rutubetten sonra, sadece kuruluk olan kalır, ancak rutubetten kuruluk tamamen kurtulmaz. Ona karıştı̆ında, ağır ateşte pişirmek kaydıyla ancak, onu eritir. Pişmiş yağ veya suda bir cisim (madde) olarak toplanır. Bu yolu öğrendiğimizde, kükürdü kırmızı veya beyaz olan iksirde, kırmızının daha üstün olmakla birlikte, kükürdünün çoğunlukta (daha hakim konumda) olduğunu bulduk. Deneyle beyaz arseniği daha kolay elde ettik. Genel hükümler olarak, bu sonuçlara doğru denir. Bundan sonra kırmızılaşturma işleminde elde etmek istediğimiz sonucun ikinci bir yararı daha var. $O$ da ateşin kızartığı şeylerle onu (cevheri) kızıllaştırmamızdır. Bu da sularla olur. Bu sular sarıyı boyayabilir, beyazlaștırır; kızıllaştırıcı olur.

\section{Dördüncü Kısım \\ (Kaynak Yapıcı Cevher)}

Buradaki kaynaşurıcı cevher rutubetlerin hepsini toplayan bir cevherdir ve bunu ateş ayıramaz. Daha önce de belirttiğimiz gibi, bunlar kaynaştıran yağlardan ortaya çıkt.

\section{Beşinci Kısım \\ Sabit Cevherler Hakkunda}

Sabit ve mevcut belirleyici cevheri düşünüp, [elde etmek] istediğimizde ateșten kaçmayan, eriyen veya erimeyen maddeleri bulduk. Ancak eriyen veya eriyik olarak daha yakın ve daha iyi olan benzer karışımda maddelerin hepsinin bize yararlı olduğunu belirledik. Bunlar bütün cisimlerin toplu olduğu müddetçe kendilerine herhangi bir şey karışması mümkün olmadığını gösterdi. Bir şeyin parçaları küçüldüğü zaman ona bir şeyin 
karışması mümkün olmaktadır, yani [ufalanmadıkça cismin sabit kalması daha mümkündür].

Sabit bir şeyin kendisini kızartması mümkün olursa, ateşte kendi durumuna döner. Bu durumda cismin kendisini yakarız ve yakmaksızın kilislenmesi (kireçlenme, calx) mümkün olursa, bunu uygularız. Biz bunu cisim en küçük zerrelerine ayrılıncaya kadar yaparız; öyle ki, cisim artık daha küçük parçalara ayrılmayacak kadar küçük parçacıklara ayrılmış olsun. Bu işlemde türünün ne olduğu ortadan kalkar. (Cismin parçaları o kadar küçülür ki ne olduğu belirsiz hale gelir). Aristototeles'in 'doğal koku (es'samme-i tabii) olarak açıkladığı, parçalanma ile türün şekli ortadan kalkar. Bunun böyle olduğunu ortaya çıkardığımıza göre, bizim için istediğimiz şeye ulaşmış olduk. Gördük, bildik ve doğru bulduk ki zerrenin daima gümüşten alınması, ya da kurşundan alınması uygun olur. Alun için ya altundan zerre alınır ya da bakırdan zerre alınıp, altun yapılır. Denildi ki, lapis lazuli, beyaz üstübeç ve bakır altun için daha uygundur. Bize göre, gümüş için de kireçlenme mümkün oldu. O kireç taşı ve beyaz üstübeçle yapıldı. Onlar da beyazlaştırıcılardandır. Altın için de kırmızı zerrecikler gerekti. Zencefre kızıllaşturıcılardan biri olarak kullanıldı.

\section{Altunci Kisım \\ (Terkip Hakkunda)}

Beyaz boya için, yağ ve kireç taşı kullanılır. Bütün bunlar da beyazlaştırıcıdır. Kızıllaşturmak için hepsi kızartıcı olan boya, yağ ve kireç taşı kullanılır. Bu durumda, onları aralarında birleştirmek ve tek cevher olarak tespit etmeye ihtiyaç duyarız. Tek cevher olması ve sabitleştirilmeleri için aralarında birleşmeleri gerekir. Bu da birbirlerine girmesi ve karışmalarıyla mümkün olur. Bunun için yaptığımız deneylerden gördük ki; tatlı sular karıștırılıp, iyice mezcedildiğinde, kurutulup, bağlandığında birbirine bağlanır, yapışır; öyle ki sabit madde uçucu madde arasına karışsa bile, uçucu madde yine de uçar. Eğer uçucu madde az olursa onunla kalır. Çözülen şeyler, çözülür, ancak güçleri onlarda kalmak suretiyle, yeniden bağlanır. Çoğunlukla bunun böyle olduğunu gördük. Tabiat bilimlerinden, örneğin tuz, nişadır, zaç gibi, asli cevherleri sudan olan cevherden şeylerin çözülüp aktığını öğrendik. Diğer kanunlardan bildik ki, bu adı geçen cevher çözülünce veya eriyince, bu erime işi asli faaliyetlerinden onları men etmez. Bu kıyasın doğruluğunu deney de onayladı ve bu maddelerin enerji ve 
güçlerinin asli kaynakları baki kıldığı görüşünün doğruluğunu görmemizde yardımcı oldu. Bunun için en uygun cisimlerin analizi, çözülmelerini sağlamak, karışurmak asıl cevherlerini bir tek unsur olarak keskinleştirmek için ona nüfuz etmek, kaynaşturmak, ateşe dayanıklı olarak sabitlenmesi için birleştirmek, sonra karıștırmak ve akıtmak fiillerinin en uygun işlemler olduğunu gördük. [Tozu] kullandığımız zaman dövmeyi, öğütmenin uygun olduğunu; sürekli karışabilen, çözülebileni keskin sularla sulamakla bunun analiz yerine geçmesinin mümkün olacağını zannettik. Bu işlemleri biz birçok şeyi denemek için uyguladık. Belki başarılı oldu, belki de olmadı. Bunun başarısızlığı ya aletlerin eksik olması ya da işlemlerin kusurlu olduğu için veya sonuçlandırması çok zor olan basit bazı diğer sebeplerden dolayıdır.

Biz bu iki kısımda iksir sanatını tanımlamak için dayanak bulduk; dayandık. Allah'a şükürler olsun ki; istenen gayeye ulaştk. Beyaz için asıl yani $o ̈ z$, geliştirilmiş cıva ve kükürt veya beyazlaşturılmış arsenik ve üstübeç veya karıştırılmış diğer cisimler ya da iksirin ta kendisidir. Sarılar için kökler ise geliştirilmiş kükürt boyası, geliştirilmiş cıva ve beyazlaştrrılmış kükürt ve cisim halinde kireç taşıdır. Bunların en iyisi el-iksirdir. Bütün bunların kızartılması ve bunların birleştirilmesiyle tam iksir olur.

\section{Yedinci Kısım \\ (Madeniyatun Dışındakiler Hakkında)}

Sonradan, kıl, yumurta, kan ve hayvanın vücut parçalarının birçoğundan iksir elde etmenin mümkün olduğunu duyduk. Bunların eriyik cisimlere yapışkanlığı ve etkisi olup olmadığını denemek için analiz ve çözüm yaptığımızda miktarın önemli olmadığını bulduk. Ancak duman ise cisimlere yapışıp gümüşün üst kısmını sarartığını belirledik. Yine kızdırılmış gümüş de ona daldırılınca, onu (kükürdü) etkiledi. Böylece kendisinde boya ve yapışkanlık olduğunu belirledik. Yine biz kan, kıl ve tuzlu pişirilenlerin hepsinin sularının tuza dönüştüğünü öğrendik. Yine buradaki deneylerden boyayı ayrıntılı anlatmak ve ondan çıkacak sonuçlara açıklık getirmek istediğimiz zaman, ancak ateşle yükseltmekle [amacımıza erişmemizin] mümkün olduğunu öğrendik. Yine bildik ki, ondan ilk damıtularak elde edilen sıvı su ve yağdır, çünkü bu ateşe daha dayanıklı veya sabittir. Biz bu çıkan cevheri çok düşük bir ateşle muamele ettiğimizde kap ve imbikteki suyun damla damla aktığını belirledik. Daha sonra yağ akmaktaydı. Biz bunun iki- 
sini (orada yağ ve su olarak ne varsa) tükenene kadar damla damla akıttık [Bunların akışı bitince, orada sadece] artıklar kaldı.

Biz tortuyu tekrar tekrar yaktık, öyleki orada ateşe dayanıklı kireç oluştu. Bu durumda da kireç elde edildi. Boyayı yağa koyduğumuzda, onları iyice birbirine karışturmamız ve kendi suyunda pişirmemiz gerektiğini belirledik. Maddenin suyu tuzlu keskin ise ve keskinlik (asit?) de nışadıra dönüşüyorsa, biz bu durumda o maddeyi ağır ateşte boyası akana kadar pişirdik. Daha sonra yağını aldık ve onu normal keskinlikteki sularda pişirdik, ta ki onu temizleyip beyazlaşturana ve kirecini temizleyip beyaz toz haline getirene kadar bu işleme devam ettik. Su, bu durumda madeniyattaki cıva gibi idi. Yağ da kükürt veya madeniyattaki arsenik gibi oldu. Kireç de madeniyattaki kireç gibi oldu. Onda biriken iksir de madenlerdeki iksir gibi idi. Ancak bu işlem, kalite bakımından en üstün, en zengin ve en çok uygulanandır.

\section{Sekizinci Kısım \\ (Demirin Yükseltmesi İçin Alınan Tedbirler ve Konuyla İlgili Diğer Șeyler)}

Ancak cıva, şayet beyaz renkte ise, onu kurşun dumanı ile alıp dondururuz. Şayet o, sarı renkte ise kurşun dumanına tutarız; beyaz ise üzerine kül ve gümüş renkli turunç ekleriz (serperiz). Bunu da bir çukur kap veya çukur bir yerde yaparız. Cıvanın sarı renk alması için alun renkli turunç veya kükürt veya külü onun üstüne dökeriz. Bu eriyiğin üstüne erimiş kurşun dökünce, kurşun onunla karışmaz. Bu işlemi o terkip donup taş gibi olana kadar tekrarlarız. Belki de bu işlemi içinde buz olan bir kapta yaparız.

Dibeğin (havanın) kolunu kurşuna batırırız; o zaman bu terkip donar. Terkibi dibeğin içine koyup, birkaç defa demir dibek eli ile karışturıp, bırakırız. Şayet donmasını istemiyorsak onu dövülmüş hardalla döveriz ve bu işlemi suda yaparız ve bu işleme ondaki ateş etkisini kaybedene kadar devam ederiz. Sonra tuz ve zaçla karıştırırız ve onu aynı yolla birkaç defa yükseltiriz.

Kırmızılık içinse, kükürt kırmızılığı suyunda kızdırıldıktan ve yükseltildikten sonra suya batırırız ve onu yükseltiriz ve o terkip, tupkı develerin bir araya toplanması gibi, şişenin boynunda toplanana kadar, bu işleme devam ederiz ve kabın ağzını kapatırız. Her yükseltme ve boğazda toplanma, damıtmadan sonra görülür. Arsenik ve kükürt için ise en doğru görülen 
işlem şöyle olur: onlar ince bir şekilde demir talaşı ile iyice dövülür, hatta kuruyuncaya kadar sirke ile pişirilir. Ondan sonra kızdırılır (isıtulır), sonra yükseltilir ve tuzla, zaçla, talk taşı ile kireç taşı ile ve kemik kireciyle pişirilmesi de uygundur.

Zaçtan ayırdığımız zaman [söz konusu olan terkip] tuz veya bor gibi toplanır ve yükseltme işlemi birkaç defa süzülerek devam eder, hatta neticeye ulaşana kadar işlem sürdürülür. Kıl yağı veya başkalanı ise sürekli kaynayan ateşten sertleşinceye, hatta katulaşıncaya kadar işlem devam ettirilir; sonuca, ancak böyle bir işlemle ulaşmak mümkündür. Sonra [terkip] mutedil kaynatma işlemi ile suda pişirilir, hatta onun siyahlığı çıkıp beyazlaşana kadar bu işlem devam ettirilir.

\section{Kireçlenme İşlemi Hakkındaki Kısım}

Cisimler bazen nişadır ve sirke ile karışturılır ve bazen de öğütülmüş tuz, nişadır ve kibrit gibi şeyleri kabul edecek hale gelene kadar yakıcı şeylerle yakılır. Bazen de cıvaya daldırılarak, cıva ondan birkaç defa yükseltilir, ta ki zerrecikler kalana kadar bu işlem devam ettirilir. Ondan sonra beyaz cisim elde edilmek istenildiğinde, damıtılmış tuzlu su ile damıtılır ve dövülür; sonra parçaları bütünleşip, bir kütle haline gelene kadar ocakta bırakılır.

Sarı cisim elde etmek istendiğinde, zaç suları ile tek tek ve bütünüyle kırmızı kükürt ile veya başkasıyla veya yumurta yağı ile muamele edilir. Kızdırmağa terkip kızarana kadar devam edilir, parçaları çok küçük zerrelerine ayrılana kadar da bu işlem sürdürülür.

\section{Tahlil (Çözümleme)}

Çözümleme için gördüğümüz en kolay yollardan biri, ilaçların (akakir) doğasını eriyen veya çözülmeye müsait olan şeylere döndürmektir; onları, tuzlar ve zaçlar vasıtasıyla parçalarına ayırmaktır.

Bunların kuvvetlilerinin nişadır olduğunu gördük. Onu (terkibi) eritir, sıv kısmını döverek ve terkibi ısıtarak çıkarma işlemine nişadırı elde edene kadar devam ederiz. Bu da o cismin üzerine onu tam olarak dolduracak şekilde erimiş nişadır dökerek yapılır. Sonra kuruyuncaya kadar onu döveriz. Sonra da onu bir kepçeyle hafif ateşe tutarız. Dumanlanmağa başlayınca onu uzaklaşurırız; sonra döveriz, işlemi 10 defa tekrarlarız. Sonra onu yeniden tekrar suya tutarız. O kütle haline gelene kadar bu işlemi tekrar ederiz. Kütle 
haline gelmesi (mum şeklini alması) için, suda eriyene ve hiçbir pürüz kalmayacak hale gelene kadar bu işlemlere devam ederiz. Bu da 10 defa su vermek suretiyle yapılır. Bu işlemi çoğalturız. Şayet birleșimi döverek yapmak istiyorsak, en doğrusu, kırmızı iksirlerdir. Bunun için eriyik halindeki nişadır, zaçla sulandırılmış olarak ısıtılır ve sonra terkip kızarana kadar bu işlem devam ettirilir; yükseltilir ve sonra eritilir. Ancak hayvansal maddeler kendi sularıyla sulandırılırlar. Bunlar (hayvani sular) incelendiğinde analiz edip, eritip, istersek başı bağlı bir şişe içinde gübreye gömeriz. Bunu sürekli tekrarlarız veya sirke küpüne veya rutubetlerden bir başkasının içine gömerek veya kuyulara, kör, keskin suların içine asarak, bu işlemi yaparız. Bu kör, keskin sular pişirilerek kaynatılır. Birkaç defa kireç taşı ile muamele edilir. Bu kireç taşı öyle keskindir ki içine bir tüy daldırıldığında onu yakar. Nişadır onun içine bırakılır.

İstenirse [hayvansal maddelerden] kızıllaștırılmış kükürt ve zaç yapılır. Bunun için 40 gün ile 3 ay arasında bir süreye ihtiyaç vardır. Sular çözülünce onları bir araya koyarız; onları tekrar birleştiririz ve karışana kadar bir kap içine koyup, kızgın bir küle gömeriz ta ki pıhtılașıp, katılaşana kadar bu işlemi devam ettiririz; sonra o kurur ve kütle halini alır. O iksirdir; iksir olur.

Belki keskin sularla onu döveriz öyle ki, bu sulara iksir karışana kadar ve eriyene kadar işlemi devam ettiririz ve sonra onu ateşe tutarız. Hepsinin buharlaşması için, bu işlemi 30 defa veya daha da çok tekrarlarız. Eğer o zaman terkip tamamen buharlaşırsa, bil ki doğru yapun. Ancak kireç tortusunda hataya düştün. Ondaki buharlaşma artmasın ve hepsi buharlaşmasın diye kireci artır, hatta erit ve çöz; hatta içindeki yapışkanlık artsın. Ancak, ondaki maddelerin belli miktarlarını korumalıyı.

\section{Dokuzuncu Kısım (İşlem Bittiğinde İksirin Sıfat Nedir)}

Bu iksir kendi boyasıyla boyanır ve yağının içine dökülür ve yağ ve kireç taşı kalır. Bu da çok ince boya ile çok katı kireç arasında birleştirici bir maddedir. Cıva ise boyayı tașıyıcıdır. Kıvamlı yağ, boyayla boyanan kirece bırakıldığında aynı ağırık veya aynı katılık, aynı hacimdedir. Onlar iyi karıştıkları için ayrılmazlar. Kırmızı boyanın örneği de ateş unsurlarındandır. Yağın karşılığı havadır. Cıvanın karşılığı sudur. Kirecin karşılığı 
topraktur. Beyaz ise üçle olur. (su, toprak, hava). Orada, ateş yoktur. Sarı ise dördüyle olur ${ }^{19}$.

Allah'ın övgüsü, yardımı ile zilkade [ayının] orta onunda 690 (H.) (1291 M.) senesinde Bağdat'ta bu risale tamamlanmıștır. Allah'a övgü; efendimiz, velimiz Hz. Peygamber Muhammed'e, temiz ve güzel ehline ve kibar, seçkin ve kaliteli sahabelerine dua olsun. Allah bize yeten ve en iyi destektir.

${ }^{19}$ Burada sōz konusu olan dört unsurdur; toprak, su hava ve ateş bu teoriye göre temel dört unsur olup, bütün maddelerin temel unsurlarıdır. İbn Sina burada bu teoriye işaret ederek, simya açısından temel maddeler olarak kabul edilen cıva ve kükürdün simya açısından yapısına vermektedir. 